Review

\title{
A Short Review on the Electrochemical Performance of Hierarchical and Nitrogen-Doped Activated Biocarbon-Based Electrodes for Supercapacitors
}

\author{
Glaydson Simões dos Reis ${ }^{1, *(D)}$, Helinando Pequeno de Oliveira ${ }^{2} \mathbb{D}$, Sylvia H. Larsson ${ }^{1}$, Mikael Thyrel ${ }^{1}$ \\ and Eder Claudio Lima ${ }^{3}$ D
}

1 Department of Forest Biomaterials and Technology, Swedish University of Agricultural Sciences, Biomass Technology Centre, SE-901 83 Umeå, Sweden; sylvia.larsson@slu.se (S.H.L.); mikael.thyrel@slu.se (M.T.)

2 Institute of Materials Science, Federal University of Sao Francisco Valley, Petrolina 56304-205, Brazil; helinando.oliveira@univasf.edu.br

3 Institute of Chemistry, Federal University of Rio Grande do Sul (UFRGS), Av. Bento Gonçalves 9500, Porto Alegre 91501-970, Brazil; profederlima@gmail.com

* Correspondence: glaydsonambiental@gmail.com or glaydson.simoes.dos.reis@slu.se

Citation: Reis, G.S.d.; Oliveira, H.P.d.; Larsson, S.H.; Thyrel, M.; Claudio Lima, E. A Short Review on the Electrochemical Performance of Hierarchical and Nitrogen-Doped Activated Biocarbon-Based Electrodes for Supercapacitors. Nanomaterials 2021, 11, 424. https://doi.org/ 10.3390/nano11020424

Academic Editor: Jie Wang

Received: 8 December 2020

Accepted: 30 January 2021

Published: 7 February 2021

Publisher's Note: MDPI stays neutral with regard to jurisdictional claims in published maps and institutional affiliations.

Copyright: (c) 2021 by the authors. Licensee MDPI, Basel, Switzerland. This article is an open access article distributed under the terms and conditions of the Creative Commons Attribution (CC BY) license (https:// creativecommons.org/licenses/by/ $4.0 /)$.

\begin{abstract}
Cheap and efficient carbon electrodes (CEs) for energy storage systems (ESS) such as supercapacitors (SCs) and batteries are an increasing priority issue, among other things, due to a globally increasing share of intermittent electricity production (solar and wind) and electrification of transport. The increasing consumption of portable and non-portable electronic devices justifies research that enables environmentally and economically sustainable production (materials, processing techniques, and product design) of products with a high electrochemical performance at an acceptable cost. Among all the currently explored CEs materials, biomass-based activated carbons (AC) present enormous potential due to their availability and low-cost, easy processing methods, physicochemical stability, and methods for self-doping. Nitrogen doping methods in CEs for SCs have been demonstrated to enhance its conductivities, surface wettability, and induced pseudocapacitance effect, thereby delivering improved energy/power densities with versatile properties. Herein, a short review is presented, focusing on the different types of natural carbon sources for preparing CEs towards the fabrication of SCs with high electrochemical performance. The influences of ACs' pore characteristics (micro and mesoporosity) and nitrogen doping on the overall electrochemical performance (EP) are addressed.
\end{abstract}

Keywords: biomass resources; pore structure; nitrogen doping; supercapacitors

\section{Introduction}

The application of biomass residues as the main precursors for producing carbon electrodes (CEs) for energy storage systems (ESS) has been gathering great attention due to its low processing cost and its economic and technical sustainable approaches. ESS, such as batteries and supercapacitors (SCs), are the key to the sustainable development of autonomous electronic devices [1,2].

SCs are promising energy storage devices, and have attracted extensive attention due to their rapid charge and discharge rates, high power density, and long life [3]. Two main mechanisms are responsible for storing energy in supercapacitors: the electrical double layer capacitance (EDLC) and the pseudocapacitance [4-6]. The EDLC behavior is a characteristic of carbon derivatives with a high surface area favored by available sites for charge accumulation in a Helmholtz double layer at the electrode-electrolyte interface. The access of charges to these sites is critical for a fast charge-discharge process. These properties limit the energy density in EDLC-based materials. However, pseudocapacitive materials (metals oxides and conducting polymers) are favored by an additional term to the EDLC due to the response in terms of redox reactions, electrosorption, and intercalation 
that are characterized as fast charge-transfer processes, contributing to the high values for energy density in supercapacitors. The typical drawback in pseudocapacitance candidates is low conductivity (in metal oxides) and poor capacitive retention (fast degradation) in conducting polymers. Consequently, the synergistic interaction between components tends to preserve each material's advantages, minimizing the drawbacks. The investigation of nanocomposites from materials with outstanding EDLC and pseudocapacitance is a critical topic in the literature.

The development of composites that combine pseudocapacitive behavior and EDLC response in highly porous structures (favored by high surface area and superior electrical conductivity) represents an important strategy to reach electrodes with outstanding electrochemical performance. Zhao et al. [7] reported the development of high energy density and ultrahigh power density from the assembly of electrodes in the form of porous carbon pillars doped with heteroatoms.

Different candidates have been proposed to be applied as EDLC supports (such as graphite, graphene, carbon nanotube, and activated carbon) based on these considerations. However, the scale-up of devices based on these materials is obstructed by the prevailing time-consuming and energy-wasting procedures. Because of this, it is preferable to use easily accessible, renewable, and sustainable materials such as biomass-derived carbon materials [8]. For instance, graphite is a widely used material for energy storage systems fabrication [2]. However, graphite-based devices have reached energy densities close to their theoretical limit, which cannot satisfy the increasing need for higher storage capability, such as electric vehicles and grid energy storage [2,8]. In this sense, to push forward alternative electrodes' technology there is an imperative need for the design and development of next-generation energy storage devices with similar and/or better electrochemical performances than graphite-derived materials $[2,8]$.

Despite advantages related to the corrosion resistance and ballistic electronic transport in carbon derivative systems (such as biomass-based materials) for use in electrodes, there is a crucial concern relative to the optimization in the energy density-power density of devices in association with reduction of costs in truly scalable systems, due to the typical high-cost processes involving the production of nanoscale-based systems [2].

The production of highly porous carbon materials from biomass is typically based on the carbonization or pyrolysis of material followed by a step of activation (physical or chemical procedure) [9] that confers excellent surface area and porosity degree-the right conditions for EDLC systems. However, as previously described, an adequate condition for the production of high-performance electrodes is based on the combination of Faradaic (pseudocapacitance) and non-Faradaic components (EDLC).

Alternatives to incorporate pseudocapacitance in highly porous carbon derivatives involve the self-doping and artificial doping processes in porous structures. Artificial doping is based on the post-treatment of thermally treated carbon with amines, urea, or phosphoric acid [7]. On the other hand, self-doping is based on direct carbonization/pyrolysis of specific biomass rich in groups that introduce a more homogeneous distribution of heteroatoms into the structure's bulk. In addition to the pseudocapacitance, these doping elements improve the wettability and the resulting structure's conductivity.

Given this, the presence of heteroatoms (N, P, S, B, and O) in biomass is preferable, allowing that doped materials can be obtained under thermal treatment and activation. Some examples of intrinsically doped biomass sources are gelatin from animal bones and nitrogen-rich japonica seed [7], winter-jujube (source of $\mathrm{O}$ and $\mathrm{N}$ ) [9], Albizia flowers [10], Cicada slough (source of N, O, S, and P heteroatoms) [10], sharia bambusicola (source of N and Si) [11], boric acid and phosphoric acid (source of B, P, N, and O) [12], and chitosan as an essential source of $\mathrm{N}$ and $\mathrm{P}$ for self-doped heteroatom structures. It is typical for these structures that they are favored by the most straightforward strategies (one-pot methodology) [13], resulting in cost-effective electrodes and that favor scale-up based strategies. Herein, we summarize the most relevant and recent papers that explore the self-doping of carbon nanostructures with heteroatoms in highly porous carbon derivatives 
applied as electrodes for supercapacitors, resulting in high surface area materials with good conductivity and superior electrochemical performance.

\section{Effect of the Pyrolysis and Experimental Conditions on the AC and CE Properties}

The preparation and production of ACs usually occur through both carbonization and activation processes that can be performed either separately in a two-stage process or combined in a single-stage process [14-17].

Biomass carbonization is performed in the absence of oxygen, generally at temperatures between 400 and $850^{\circ} \mathrm{C}$, to produce $\mathrm{AC}$ with useful properties. However, temperatures up to $1200{ }^{\circ} \mathrm{C}$ have been reported [14-17].

Pyrolysis conditions and impregnation by chemical agents have a strong influence on the AC properties. Hence, to obtain AC with characteristics that provide CE with the finest electrochemical properties, it is crucial to find optimum experimental conditions. Generally, the literature indicates that the ACs with the finest properties are produced at high-temperature pyrolysis [14-18] as a consequence of the aromatization process in the carbon chain (enabled at high temperature) [19-21]. Bouchelta et al. [22] studied the effects of pyrolysis conditions on the porous structure of ACs made from date pits. The effect of temperature on the AC's physical properties is shown in Figure 1. Within the experimental range, they found a positive correlation between temperature and $\mathrm{S}_{\mathrm{BET}}$, which also complies with many other studies [23-25]. Figure $1 \mathrm{C}$ shows the impact of pyrolysis temperature $\left(0,300,400,500,600\right.$, and $\left.700{ }^{\circ} \mathrm{C}\right)$ on the $\mathrm{S}_{\mathrm{BET}}$ and the resulting biochars' pore volumes. The highest $\mathrm{S}_{\mathrm{BET}}$ and pore volume was achieved for the $\mathrm{AC}$ that was pyrolyzed at $700{ }^{\circ} \mathrm{C}$.
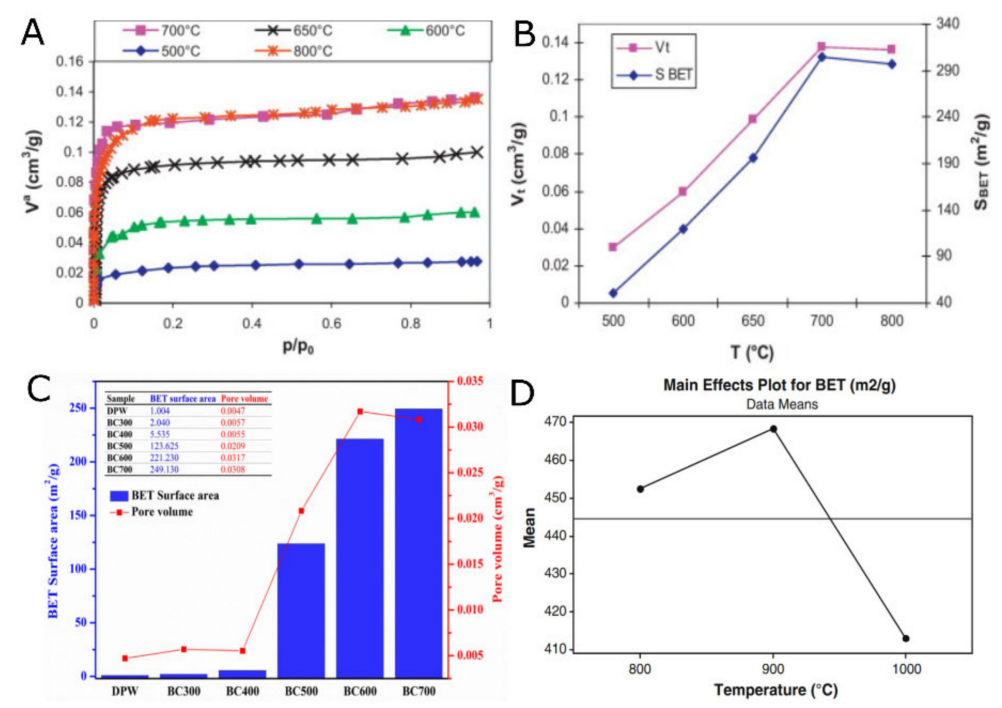

Figure 1. (A) $\mathrm{N}_{2}$ isotherms of activated carbon (AC) from date pits pyrolyzed at different temperatures. (B) Variation of $\mathrm{S}_{\mathrm{BET}}$ and $\mathrm{V}_{\mathrm{t}}$ with pyrolysis temperature [22]. (C) Effect of $\mathrm{T}$ on BrunauerEmmett-Teller (BET) specific surface area and pore volumes of biochar samples [24]. (D) Effect of carbonization temperature on $\mathrm{S}_{\mathrm{BET}}$ porous surface area [25]. (A) and (B) Ref. [22] is reproduced with permission from Elsevier, 2012. (C) Ref. [24] is reproduced with permission from MDPI (open access), 2019. (D) Ref. [25] is reproduced with permission from Springer Nature (open access), 2014.

However, high pyrolysis temperatures (over $900^{\circ} \mathrm{C}$ ) negatively impact the final $\mathrm{AC}$ characteristics [25]. This effect is mainly associated with longer holding times; the high level of solidification and shrinkage of the carbonaceous matrix results in narrowing or closing the pore entrances, thus reducing the accessible surface area $[19,20]$. Figure 1D corroborates such a hypothesis, revealing the main effects of pyrolysis temperature on $S_{B E T}$ of the ACs - the carbons prepared at $1000^{\circ} \mathrm{C}$ exhibited the lowest $\mathrm{S}_{\mathrm{BET}}$ (Figure 1D). 
In addition to pyrolysis temperature, the heating rate, holding time, and chemical activation conditions are essential parameters for the resulting CE performance [26-28]. The heating rate has a strong influence on the AC quality; at a very high heating rate, the proportion of the solid product is reduced due to higher volatilization and gas formation; this leads to shrinkage of the AC and reduction in the specific surface area [29,30]. With a lower heating rate, a higher solids yield is obtained [19-21].

Generally, a longer holding time results in that secondary char is produced in a reaction between the primary char and volatiles $[19,20,22]$.

The activation of biomass materials is performed to synthesize ACS with high carbon content, large surface area, and pore volume. Additionally, activation can vary or adjust the surface chemical properties and the pore characteristics [31-33]. Activation is considered more crucial than carbonization in terms of AC properties, although both are very important and dependents.

There are two activation processes, physical and chemical activation processes. Physical activation involves carbonization of a carbonaceous material followed by activation of the resulting char in the presence of some activating agents such as $\mathrm{N}_{2}$, and $\mathrm{CO}_{2}$, air, steam, or a mix of these. Otherwise, in the chemical activation process, a chemical agent $\left(\mathrm{ZnCl}_{2}, \mathrm{H}_{3} \mathrm{PO}_{4}, \mathrm{NaOH}\right.$, or $\left.\mathrm{KOH}\right)$ is applied to activate the biomass while the carbonization occurs [31-33]. In physical activation, eliminating a large amount of internal carbon mass is necessary to obtain a well-developed carbon structure. In contrast, in the chemical activation process, all the chemical agents used are dehydrating agents that influence pyrolytic decomposition and inhibit the formation of tar, thus enhancing the yield of carbon and creating active pores and well-developed porosity.

The main factors affecting physical activation include the type of carbon precursors, their particle size, gas flow, heating rate, carbonization time, and carbonization temperature. Chemical activation has the advantage of using low carbonation temperature, short holding time, AC with high carbon content, easy to control the porosity, and elevated SSA [31,33]. On the other hand, it also has some disadvantages: drastic corrosivity and washing process and costly $[32,33]$. The main factors affecting chemical activation include the type of activating agent, mixing method, the mass ratio of activating agent to carbon precursor, and heating method [31].

\section{Biomass-Based Electrodes for Supercapacitors}

Biomass residues are widely available as plant residues (bamboo, coconut, and peanut shells, petals, soybean, etc.) and raw materials from animals (honeycomb, cattle bone, leather, etc.), and these biomaterials can be used as raw materials for manufacturing CEs for energy storage systems such as supercapacitors.

SCs store and deliver energy by ion adsorption on the surface of the electrically conductive porous CEs. Therefore, CEs exhibiting elevated SSA and developed porosity display quite often better electrochemical properties.

To date, ACs have been the most used electrode materials in SCs due to their easy preparation methods, very high porosity, and SSA, and excellent electrical conductivity [34-44]. Both the biomass precursor and the preparation method are crucial for the ACs properties and greatly influence the final CEs' electrochemical features (See Table 1).

In addition to their wide availability and low cost, biomass precursors are suitable for $\mathrm{CEs}$ preparation due to the abundance in the functional groups on the resulting $\mathrm{CE}$ structures $\left(-\mathrm{COOH},-\mathrm{OH},-\mathrm{NH}_{2}\right)$, and the significant variability in composition, morphology, and textural properties-all very important to reach advantageous electrochemical properties. 
Table 1. Electrochemical properties of biomass-based electrodes for supercapacitors (SCs) under different conditions.

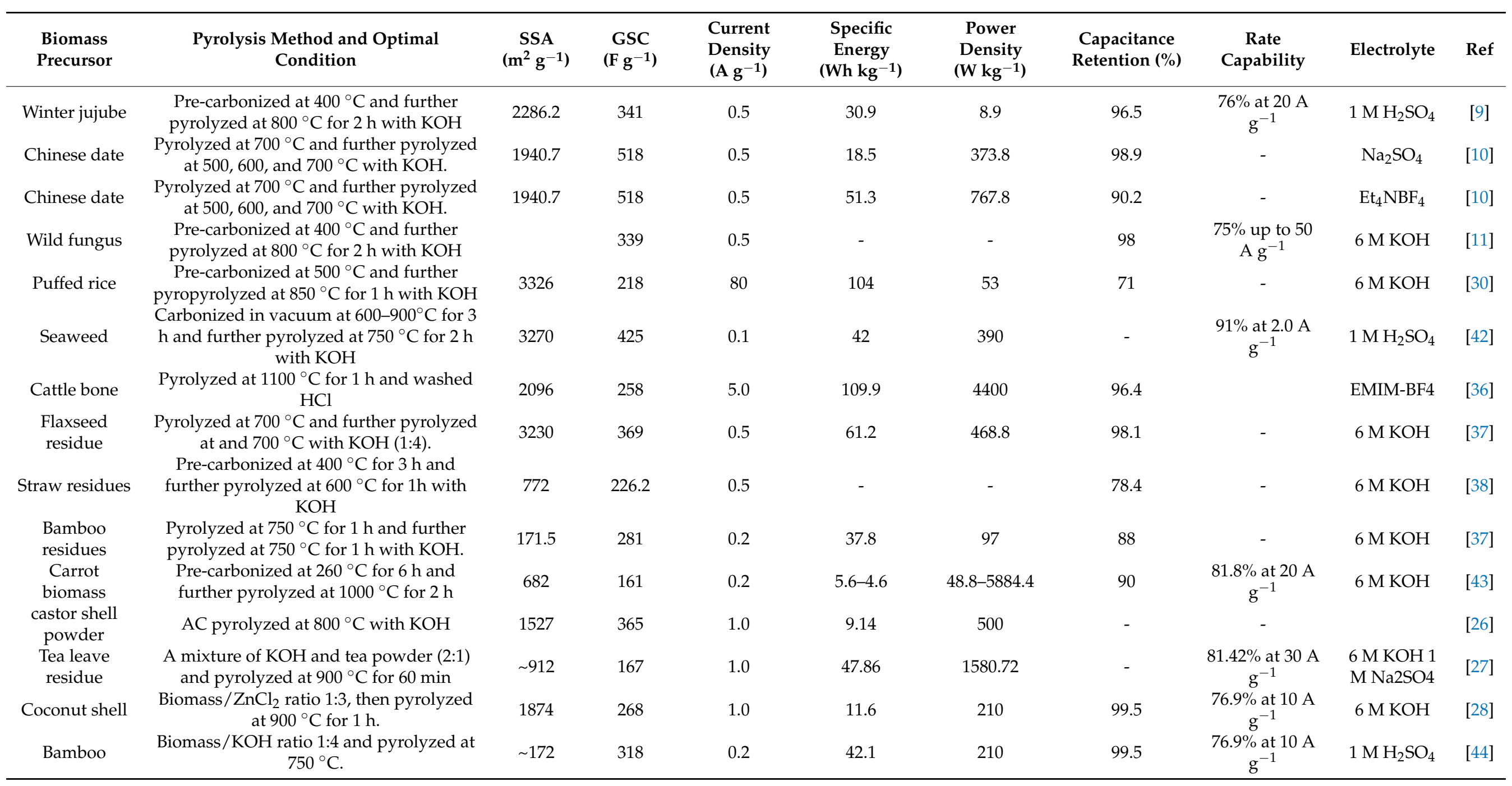


Table 1. Cont.

\begin{tabular}{|c|c|c|c|c|c|c|c|c|c|c|}
\hline $\begin{array}{l}\text { Biomass } \\
\text { Precursor }\end{array}$ & $\begin{array}{c}\text { Pyrolysis Method and Optimal } \\
\text { Condition }\end{array}$ & $\begin{array}{c}\text { SSA } \\
\left(\mathrm{m}^{2} \mathrm{~g}^{-1}\right)\end{array}$ & $\begin{array}{c}\mathrm{GSC} \\
\left(\mathrm{F} \mathrm{g}^{-1}\right)\end{array}$ & $\begin{array}{l}\text { Current } \\
\text { Density } \\
\left(\mathrm{A} \mathrm{g}^{-1}\right)\end{array}$ & $\begin{array}{c}\text { Specific } \\
\text { Energy } \\
\left(\mathrm{Wh} \mathrm{kg}^{-1}\right)\end{array}$ & $\begin{array}{c}\text { Power } \\
\text { Density } \\
\left(\mathrm{W} \mathrm{kg}^{-1}\right)\end{array}$ & $\begin{array}{l}\text { Capacitance } \\
\text { Retention }(\%)\end{array}$ & $\begin{array}{c}\text { Rate } \\
\text { Capability }\end{array}$ & Electrolyte & Ref \\
\hline Shaddock skin & $\begin{array}{l}\text { Carbonized at } 900{ }^{\circ} \mathrm{C} \text { for } 2 \mathrm{~h} \text { under } \mathrm{Ar} \text { and } \\
\text { further pyrolyzed at } 1200^{\circ} \mathrm{C} \text { for } 1 \mathrm{~h} \text { under } \\
\text { vacuum }\end{array}$ & 2327 & 152 & 1.0 & 11 & 5600 & 97.6 & $\begin{array}{l}87 \% \text { at } 100 \mathrm{~A} \\
\mathrm{~g}^{-1}\end{array}$ & $\begin{array}{l}\text { EMI TFSI + } \\
\text { EMI BF }_{4}\end{array}$ & [45] \\
\hline Peanut shells & $\mathrm{FeCl}_{3} / \mathrm{MgCl}_{2}$ activated sample at $800^{\circ} \mathrm{C}$ & 1401.45 & $\sim 247$ & 1.0 & 32.7 & 588.3 & 96.3 & $\begin{array}{c}81.8 \% \text { at } 10 \\
\mathrm{~A} / \mathrm{g}\end{array}$ & $1 \mathrm{M} \mathrm{Na}_{2} \mathrm{SO}_{4}$ & [46] \\
\hline Peanut shells & $\mathrm{FeCl}_{3} / \mathrm{ZnCl}_{2}$ activated sample at $800{ }^{\circ} \mathrm{C}$ & 1427.81 & $\sim 186$ & 1.0 & 22.9 & 523.8 & - & & $1 \mathrm{M} \mathrm{Na}_{2} \mathrm{SO}_{4}$ & [46] \\
\hline $\begin{array}{l}\text { wood sawdust } \\
\text { and tannic } \\
\text { acid }\end{array}$ & Potassium chloride + sodium thiosulfate & 2650 & 200 & - & $47-51$ & - & $97-100$ & $\begin{array}{c}80 \% \text { at } 40 \mathrm{~A} \\
\mathrm{~g}^{-1}\end{array}$ & $\begin{array}{l}\text { aqueous } \\
\text { electrolyte } \\
\left(\mathrm{H}_{2} \mathrm{SO}_{4}\right)\end{array}$ & [47] \\
\hline $\begin{array}{l}\text { wood sawdust } \\
\text { and tannic } \\
\text { acid }\end{array}$ & & 2650 & 160 & - & $32-36$ & 140 & $97-100$ & $\begin{array}{c}75 \% \text { at } 40 \mathrm{~A} \\
\mathrm{~g}^{-1}\end{array}$ & $\begin{array}{l}\text { Organic } \\
\text { electrolyte }\end{array}$ & [47] \\
\hline $\begin{array}{l}\text { foxtail grass } \\
\text { seeds }\end{array}$ & $\begin{array}{l}\text { Biomass was mixed with } \mathrm{NaHCO}_{3} \text { and } \\
\mathrm{KHCO}_{3}(1: 1: 1) \text { and pyrolyzed at } 700{ }^{\circ} \mathrm{C} \text { for } \\
2 \mathrm{~h} \text {. }\end{array}$ & & 358 & 0.5 & 18.2 $\mathrm{Wh} \mathrm{L}^{-1}$ & - & - & $\begin{array}{c}91.2 \% \text { at } 2.0 \mathrm{~A} \\
\mathrm{~g}^{-1}\end{array}$ & $6 \mathrm{M} \mathrm{KOH}$ & [48] \\
\hline soybean & $\begin{array}{l}\text { Pre-carbonized at } 400^{\circ} \mathrm{C} \text { for } 2 \mathrm{~h} \text { and } \\
\text { further pyrolyzed at } 7500^{\circ} \mathrm{C} \text { for } 2 \mathrm{~h} \text { with } \\
\mathrm{KOH}\end{array}$ & 2251 & 248 & 0.1 & - & - & 98.75 & $\begin{array}{l}56.7 \% \text { from } 0.1 \\
\text { to } 20 \mathrm{~A} \mathrm{~g}^{-1}\end{array}$ & $6 \mathrm{M} \mathrm{KOH}$ & [49] \\
\hline Macroalgae & $\begin{array}{c}\text { Hydrothermal carbonization }+ \\
\text { conventional pyrolysis with } \mathrm{ZnCl}_{2}\end{array}$ & $\sim 2000$ & 202 & 0.5 & 7 & 3000 & 96 & $\begin{array}{c}90 \% \text { at } 10 \mathrm{~A} \\
\mathrm{~g}^{-1}\end{array}$ & $6 \mathrm{M} \mathrm{KOH}$ & [50] \\
\hline $\begin{array}{l}\text { Biomass- } \\
\text { based carbon } \\
\text { nanofibers }\end{array}$ & & & 320.3 & 0.1 & 30.2 & 400 & 70.6 & 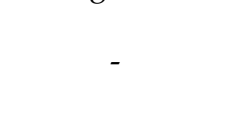 & $6 \mathrm{M} \mathrm{KOH}$ & [51] \\
\hline $\begin{array}{l}\text { Dead plant } \\
\text { leaves }\end{array}$ & Pyrolyzed at $1000^{\circ} \mathrm{C}$ in for $5 \mathrm{~h}$ in argon air & 325 & 345 & 0.5 & 43.13 & 61.34 & 87.3 & - & $1 \mathrm{M} \mathrm{H}_{2} \mathrm{SO}_{4}$ & [52] \\
\hline $\begin{array}{l}\text { Flagelliforme } \\
\text { algae }\end{array}$ & $\begin{array}{c}\text { Pre-carbonized at } 400^{\circ} \mathrm{C} \text { for } 1 \mathrm{~h} \text { and } \\
\text { further pyrolyzed at } 700^{\circ} \mathrm{C} \text { for } 2 \mathrm{~h} \text { with } \\
\mathrm{KOH} \text { activation }\end{array}$ & 2760 & 283 & 0.1 & 22 & 80 & 100 & - & $6 \mathrm{M} \mathrm{KOH}$ & [53] \\
\hline $\begin{array}{l}\text { Moringa } \\
\text { oleifera stem }\end{array}$ & $\begin{array}{l}\text { Biomass blended with } \mathrm{ZnCl}_{2} \text { (ratio 1:3) in } \\
50 \mathrm{~mL} \text { of } 2 \mathrm{M} \mathrm{FeCl}_{3} \text { solution; afterward, } \\
\text { pyrolyzed at } 800{ }^{\circ} \mathrm{C} \text { for } 2 \mathrm{~h} \text { under } \mathrm{N}_{2} \text {, for } \\
\text { the last, washed with } 2.0 \mathrm{M} \mathrm{HCl} \text {. }\end{array}$ & 2250 & 283 & 0.5 & 11.6 & 95 & 82 & - & $\begin{array}{c}1.0 \mathrm{M} \\
\mathrm{Na}_{2} \mathrm{SO}_{4} 1.0 \\
\mathrm{M} \mathrm{H}_{2} \mathrm{SO}_{4}\end{array}$ & [54] \\
\hline
\end{tabular}


Table 1. Cont.

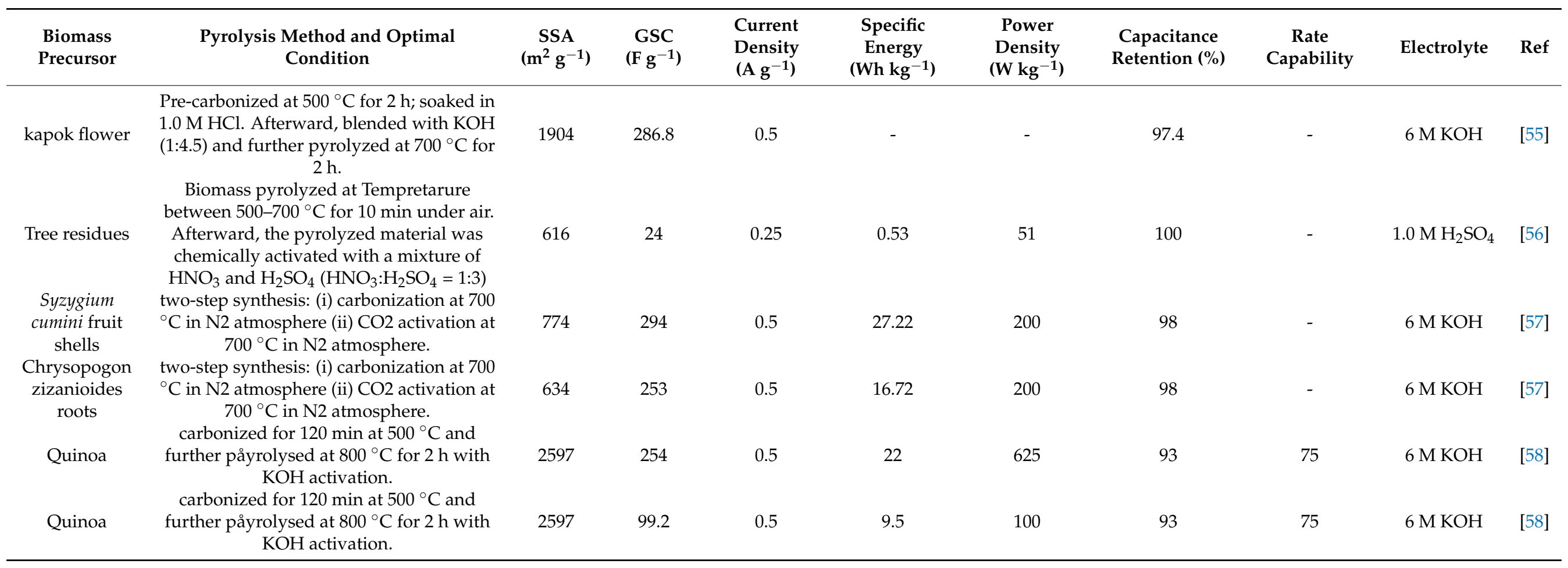

GSC-Gravimetric specific capacitance. C.E—Coulombic efficiency. 
Chen et al. [44] used bamboo residues for developing porous carbon electrodes for very efficient SCs through pyrolysis, activation, and heteroatom doping methods. They concluded that the good electrochemical properties of the $\mathrm{CE}$ were reached due to the hierarchical porous structure that was obtained by boron and nitrogen co-doping; their specific capacitances and energy densities were 281 and $318 \mathrm{~F} \mathrm{~g}^{-1}$ and 37.8 and $42.1 \mathrm{Wh} \mathrm{kg}^{-1}$ in $1 \mathrm{M} \mathrm{KOH}$ and $1 \mathrm{M} \mathrm{H}_{2} \mathrm{SO}_{4}$ electrolytes, respectively.

Jiang et al. [40] converted lignocellulosic biomass into highly porous CEs for SCs. The $\mathrm{CE}$ microstructures obtained from direct and indirect activation were highly similar. CEs displayed a specific capacitance of 80.9 and $92.7 \mathrm{~F} \mathrm{~g}^{-1}$ at the constant current density of $100 \mathrm{~mA} \mathrm{~g}^{-1}$.

Yakaboylu et al. [41] used Miscanthus grass as the primary precursor for CEs preparation through $\mathrm{KOH}$ activation. They concluded that the porosity and chemical characteristics could be controlled by the ratio between biomass/activation agent. Their experimental work resulted in an SSA of $2062 \mathrm{~m}^{2} \mathrm{~g}^{-1}$ and specific capacitance up to $188 \mathrm{~F} \mathrm{~g}^{-1}$ and cycling stability of $85-91 \%$ retention (after 1000-2500 cycles) at $0.1 \mathrm{~A} \mathrm{~g}^{-1}$ and specific energy $\left(8.0 \mathrm{Wh} \mathrm{kg}^{-1}\right)$ and specific power $\left(377 \mathrm{~W} \mathrm{~kg}^{-1}\right)$ at $0.5 \mathrm{~A} \mathrm{~g}^{-1}$. The authors concluded that the micro/mesopore volume, $\mathrm{C} / \mathrm{O}$ ratio, and surface chemistry had a considerable influence on the CE's electrochemical performance due to enhanced electro adsorption, double layer formation, and rapid ion transport.

In another work, Li et al. [9] prepared CE from winter-jujube biomass, obtaining a specific capacitance of $341 \mathrm{~F} \mathrm{~g}^{-1}$ at $0.5 \mathrm{~A} \mathrm{~g}^{-1}$ and a remarkable rate capability (76\% at $20 \mathrm{~A} \mathrm{~g}^{-1}$ ). The capacitance retention was $96.5 \%$ after 5000 cycles. Also, CE exhibited an energy density of $30.9 \mathrm{~kW} \mathrm{~h}^{-1}$ at $0.1 \mathrm{~A} \mathrm{~g}^{-1}$ and a power density of $8.9 \mathrm{~kW}$ at $5 \mathrm{~A} \mathrm{~g}^{-1}$. These results show that it is possible to use winter-jujube-derived $\mathrm{AC}$ as a high-performance $\mathrm{CE}$ for SCs.

Hou et al. [30] prepared AC from puffed rice biomass using $\mathrm{KOH}$ as an activating reagent. The biomass was pyrolyzed at $850{ }^{\circ} \mathrm{C}$, and an $\mathrm{S}_{\mathrm{BET}}$ of $3326 \mathrm{~m}^{2} \mathrm{~g}^{-1}$ was reached. The pAC was employed as CE for SCs and exhibited a high specific capacitance of $218 \mathrm{~F} \mathrm{~g}^{-1}$ at $80 \mathrm{~A} \mathrm{~g}^{-1}$ in $6 \mathrm{M} \mathrm{KOH}$ and an energy-density of $104 \mathrm{Wh} \mathrm{kg}^{-1}\left(53 \mathrm{Wh} \mathrm{L}^{-1}\right)$.

These works demonstrate that low-cost and bio-based electrode materials can be used for efficient and eco-friendly manufacturing of innovative energy storage devices with good electrochemical performance.

From Table 1, it is fascinating to note the properties of carrot biomass, reported by Liu et al. [43]. This type of biomaterial provided AC with excellent mechanical and electrochemical properties and an SSA of $682 \mathrm{~m}^{2} \mathrm{~g}^{-1}$. Using aqueous electrolyte $(6.0 \mathrm{M} \mathrm{KOH})$ and operating at a potential window between 0 and $1.0 \mathrm{~V}$, the $\mathrm{CE}$ displayed a high specific capacitance up to $161 \mathrm{~F} \mathrm{~g}^{-1}$ at $0.2 \mathrm{~A} \mathrm{~g}^{-1}$, a remarkable rate capability $\left(81.8 \%\right.$ retention at $\left.20 \mathrm{~A} \mathrm{~g}^{-1}\right)$ and energy densities of 5.6-4.6 $\mathrm{Wh} \mathrm{kg}^{-1}$ at power densities of $49.8-5884.4 \mathrm{~W} \mathrm{~kg}^{-1}$.

Besides that, when the potential operating window is expanded to $0-1.4 \mathrm{~V}$, the specific capacitance is increased from 161 to $196 \mathrm{~F} \mathrm{~g}^{-1}$ at $0.2 \mathrm{~A} \mathrm{~g}^{-1}$ and $73 \%$ retention at $20 \mathrm{~A} \mathrm{~g}^{-1}$ reaching $90 \%$ retention after 20,000 cycles, and energy densities of $13.3-9.7 \mathrm{Wh} \mathrm{kg}^{-1}$ at power densities of $70.0-8748.3 \mathrm{~W} \mathrm{~kg}^{-1}$.

\section{Effect of the Pore Structure on the Electrochemical Properties of the CEs}

The pore structure plays a significant role in the CEs' electrochemical properties [30, 42,59]. The electrolyte ions can be efficiently transported in small-sized $(<1 \mathrm{~nm})$ pores, reaching high charge storage capability at low current density [60-62]. However, the electrolyte's access and flow in small pores are hindered by increasing current density leading to a low ion exchange rate [63-65]. However, meso and macropores (pore sizes $>2 \mathrm{~nm}$ ) give an essential contribution to the rate performance of porous CEs due to the fast transport of solvated electrolyte ions even under high current density $[62,66]$.

Miao et al. [64] reported that a large number of micropores (size between 1 and $2 \mathrm{~nm}$ ) could lead to a high $\mathrm{S}_{\mathrm{BET}}$, facilitating the charge separation (due to the available sites for charge accumulation), which affects the overall energy density of the device. 
Niu et al. [36] used cattle bones as the sole precursor (without any additional activators and templates) for $\mathrm{AC}$ and $\mathrm{CE}$ preparation. The biomass was directly carbonized in an $\mathrm{Ar}$ atmosphere at different temperatures $\left(\mathrm{T}=600,850,900,1000,1100,1200{ }^{\circ} \mathrm{C}\right)$. At $1100^{\circ} \mathrm{C}$, high-defect porous AC was created with an SSA of $2096 \mathrm{~m}^{2} \mathrm{~g}^{-1}$ and a mesopore volume of $1.829 \mathrm{~cm}^{3} \mathrm{~g}^{-1}$ (see Figure 2). These properties resulted in a high electrical conductivity level $\left(5141 \mathrm{~S} \mathrm{~m}^{-1}\right)$, which is beneficial for fabricated electrodes' electrochemical properties.

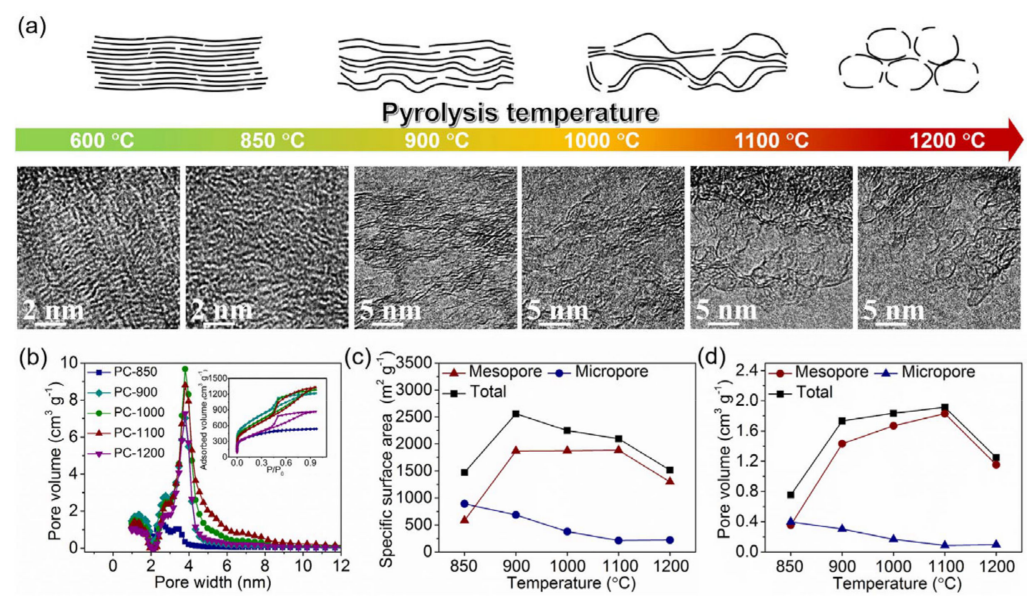

Figure 2. (a) Effect of temperature on porous formation illustrated by TEM images. (b) Nitrogen adsorption-desorption isotherms (inset) and pore size distributions of ACs. (c) $\mathrm{S}_{\mathrm{BET}}$ and (d) pore volume of ACs [36]. Figure reproduced with permission from Elsevier, 2017.

The authors concluded that the properties of the AC structures were strongly dependent on the pyrolysis temperature. At higher temperatures $\left(1100{ }^{\circ} \mathrm{C}\right)$, the mesopores were closely connected with the ultrathin pore wall, and some pores even coalesced, which generated a high SSA.

In another work, flaxseed residue was used as raw material to produce $\mathrm{AC}$ for $\mathrm{CE}$ preparation [37]. The biomass was carbonized at 600,700 , and $800{ }^{\circ} \mathrm{C}$ under Ar atmosphere for $2 \mathrm{~h}$. The ACs were further mixed with $\mathrm{KOH}$ (ratio of 1:4) and pyrolyzed at $700{ }^{\circ} \mathrm{C}$ under Ar atmosphere for $1 \mathrm{~h}$.

The authors reported that AC-flaxseed generated a dominant microporous structure with very high SSA $\left(3230 \mathrm{~m}^{2} \mathrm{~g}^{-1}\right)$ where $70.1 \%$ is composed of a large micropore structure (pore size between 1.0 and $2.0 \mathrm{~nm}$ ) (see Figure 3). Due to the reasonable amount of large micropores, the electrode reached up to 369 and $398 \mathrm{~F} \mathrm{~g}^{-1}$ in $\mathrm{KOH}$ and $\mathrm{H}_{2} \mathrm{SO}_{4}$ electrolyte, respectively. These values are justified by a pore size structure that allows a high charge storage capability in response to fast ions transportation. The resulting SCs' energy density was $61.2 \mathrm{Wh} \mathrm{kg}^{-1}$, the power density $468.8 \mathrm{~W} \mathrm{~kg}^{-1}$, and the capacitance retention was over $98.1 \%$ after 10,000 charge/discharge cycles ( $\mathrm{KOH}$ electrolyte).
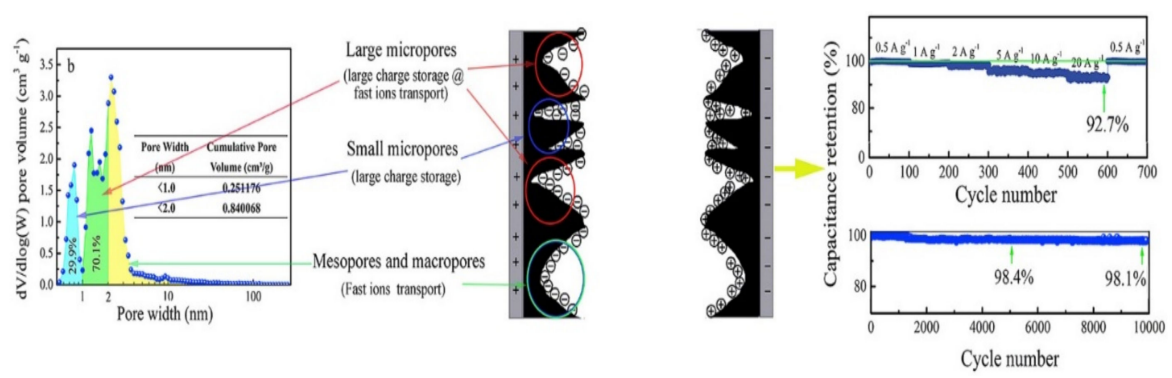

Figure 3. Influence of the pore size on the electrochemical properties of SCs [37]. Figure reproduced with permission from Elsevier, 2020. 
Gou et al. [38] used wheat straw to produce hierarchical porous CEs for SCs (see Figure 4). The carbon electrodes were made by chemical activation using $\mathrm{KOH}$ at a ratio of 3:1 in weight. Such a Figure shows that all the prepared porous CEs exhibited hierarchical three-dimensional porous structure. In Figure $4 \mathrm{~b}$ (sample 1), the morphology exhibits a honeycomb-like structure with many pores ( $420 \mathrm{~nm}$ of size). In Figure 4c (sample 2), it is shown a graphene-like structure with wider pores distribution ( $800 \mathrm{~nm}$ of mean size), and in Figure 4d (sample 3), with a resulting layer-stacking structure.

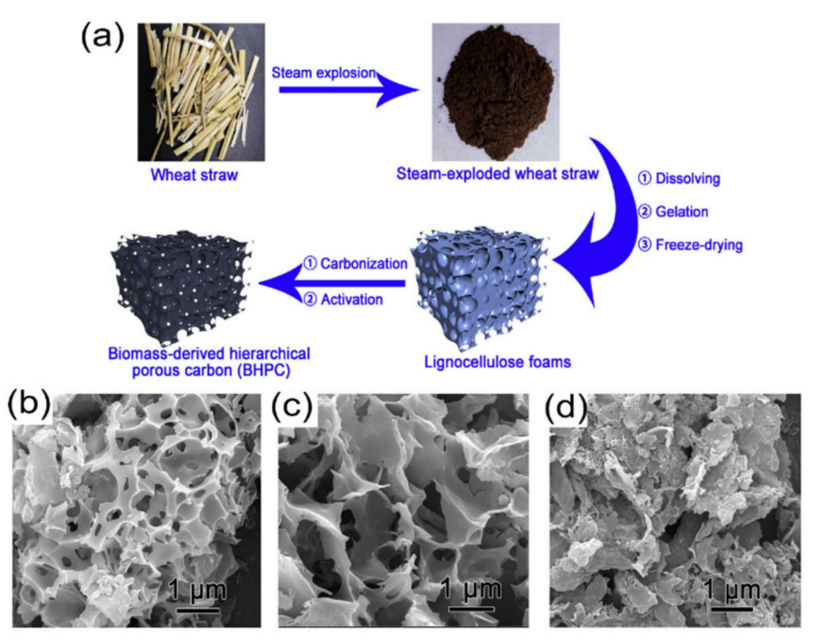

Figure 4. (a) Scheme of preparation of the biomass-derived hierarchically porous carbon under different conditions, (b-d) SEM images of different biomass-derived hierarchically porous carbons. Figure reproduced and adapted from reference [38] with permission from Elsevier, 2014.

Sample 1 displayed the highest SSA $\left(1063 \mathrm{~m}^{2} \mathrm{~g}^{-1}\right)$ compared to the other samples; however, sample 3 (with SSA of $772 \mathrm{~m}^{2} \mathrm{~g}^{-1}$ ) presented better electrochemical properties. Sample 1 with the highest $S_{\mathrm{BET}}$ did not present the best electrochemical performances because it showed a larger amount of micropores and fewer mesopore contribution. On the other hand, sample 3 presented a high amount of mesopore contributions (see Figure 4). The mesopores provide the high accessibility of a larger surface area for activation process and ion storage and pathways for fast transportation of ions into the structure.

Sample 1 presented micro and mesopore volumes of 0.39 and $0.07 \mathrm{~cm}^{3} \mathrm{~g}^{-1}$, respectively, while sample 2 exhibited between 0.25 and 0.41 . It was also related that the pore structure (interconnected three-dimensional nanostructure) provided better efficiency in the ions' electrolyte transportation-the reason for the outstanding electrochemical performance of SCs. The CEs presented a specific capacitance of $226.2 \mathrm{~F} \mathrm{~g}^{-1}$ at a current density of $0.5 \mathrm{~A} \mathrm{~g}^{-1}$.

\section{Heteroatom Doping in Porous Electrodes}

Heteroatom doping of porous materials is used to reach a high electrochemical performance of AC electrodes for energy storage systems. Among the heteroatoms, nitrogen is known as the most effective doping component. Nitrogen doping is also a feasible method because it changes the structural and physicochemical properties of CEs. Also, nitrogen sources are readily available at a relatively low cost $[67,68]$.

The nitrogen doping process can promote many defects within the AC's nano- and micro-structures and increase the $\mathrm{S}_{\mathrm{BET}}$. Besides, $\mathrm{N}$ acts as an electron donor that gives more electrons to the delocalized carbon network, increasing the electronic conductivity [69]. The higher the number of $\mathrm{N}$-dopant groups, the higher is the energy density of the CEs. As a consequence of the Faradaic reaction of $\mathrm{N}$ groups and the pore walls' improved wettability, nitrogen doping also increases the overall conductivity, which improves the electrodes' capacity. 
Usually, the nitrogen doping process is based on five types of N-carbon groups: pyrrolic, pyridinic, aminated functionalities, graphitic (quaternary), and oxynitrides (-NOx) (see Figure 5 [70]- while the graphitic-N bond results in the enhancement of the electron transfer to the structure, the pyridinic-N bonds are weakened by oxygen bonds by adsorption [71-74].

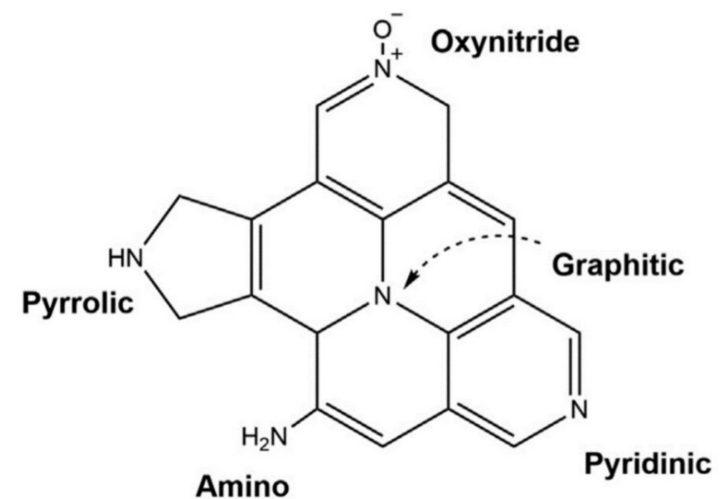

Figure 5. Main nitrogenous contents in carbons.

Many different nitrogenous sources are used in the N-doping process of AC electrodes. Ammonia, urea, melamine, thiourea are the most used ones (see Table 2). The physicochemical properties of these compounds constitute a vital factor for the doping process. For instance, ammonia is very useful for preparing $\mathrm{N}$-porous carbon electrodes due to the following reaction with the carbon source (the biomass): $\mathrm{C}+\mathrm{NH} 3 \rightarrow \mathrm{HCN}+\mathrm{H} 2$. The synthesis of hydrogen cyanide and hydrogen provokes a considerable loss of carbon atoms resulting in a more $\mathrm{N}$-doped porous structure [72,73]. Xu et al. [73] stated that the $\mathrm{N}$-doping using ammonia as an $\mathrm{N}$ source promoted two main advantages: increasing both $\mathrm{S}_{\mathrm{BET}}$ and pseudocapacitive contribution for enhanced ion adsorption.

\section{Effect of Hierarchically Porous and N-Doped Structures on Electrochemical Performance of Electrodes}

As previously reported, the textural features (surface area, pore-volume, pore width distribution) are critically important components in the ACs' 3-D hierarchical structures. In comparison with corresponding densely packed structures, the porosity facilitates ion adsorption/desorption [75].

Structural combinations of microporous, mesoporous, microporous, and hierarchical porous carbon that might offer high conductivity and characteristic interconnectivity can be produced by different strategies [75,76]. Carbon black, graphene and carbon nanotubes are typical candidates for precursors of highly porous materials [77] due to their fast charge-discharge kinetics, good stability, and environmentally harmless behavior.

To circumvent this, doping with heteroatoms (boron, nitrogen, oxygen, sulfur, and phosphorus) is performed [78], which, as a consequence of the Fermi level shift towards the valence band of the material, improves the electronic conductivity and reinforces the electron transfer.

As a consequence of higher conductivity level, the regular contribution of heteroatom doping on the overall response of highly porous carbon derivatives has been associated with the incorporation of a pseudocapacitive term into the overall electrical double layer capacitance response. This property has been associated with electrodes' superior performance in surface wettability, high capacity, and cycle stability [77]. In particular, the wettability favors the accessibility (the interfacial interaction) of carbon materials to the electrolyte solution.

The higher accessibility degree of the electrolyte ions to the microporous material structure improves the overall electrochemical, the surface polarity, and the electron-donor affinity [79]. 
Table 2. - N-doped biomass-derived carbon electrodes for SCs.

\begin{tabular}{|c|c|c|c|c|c|c|}
\hline Biomass Precursor & N Dopant Precursor & $\begin{array}{c}\text { N Content } \\
(\%)\end{array}$ & $\begin{array}{c}\text { GSC } \\
\left(\mathrm{F} \mathrm{g}^{-1}\right)\end{array}$ & $\begin{array}{l}\text { Current Density } \\
\qquad\left(\mathrm{Ag}^{-1}\right)\end{array}$ & $\begin{array}{c}\text { Capacitance } \\
\text { Retention }(\%)\end{array}$ & Ref \\
\hline Grape marcs & Urea & 2.04 & 446.0 & 0.5 & Up to 95.1 & [80] \\
\hline Alginic acid & Urea & 2.83 & 324 & 1.0 & Up to 91.5 & [81] \\
\hline Orange peel & Melamine & 3.92 & 168 & 0.7 & - & [82] \\
\hline Soybean & Ammonia & 1.37 & 243.2 & 1.0 & 96.5 & [83] \\
\hline Peach gum & Urea & 8.7 & 426 & 0.5 & 97.09 & [84] \\
\hline Glucose & hexamethylenetetramine & - & 322 & 1.0 & 54.0 & [85] \\
\hline Water chestnut & Melamine & 4.89 & 346 & 0.5 & 97.6 & [86] \\
\hline Cellulose & Urea & 7.4 & 570.6 & 1.0 & 99.8 & [87] \\
\hline Hierarchical porous carbon & $\mathrm{NH}_{3} \cdot \mathrm{H}_{2} \mathrm{O}+$ thiourea & 7.63 & 367 & 0.3 & 93.7 & [88] \\
\hline $\begin{array}{c}\text { Biomass-derived } \\
\text { hydrochar }\end{array}$ & Melamine & 4.38 & 492 & 0.1 & 98 & [89] \\
\hline Eucalyptus & Ammonium chloride & & 359 & 0.5 & 92 & [90] \\
\hline Coconut shell & thiourea & 4.62 & 360 & 0.1 & 87 & [91] \\
\hline Potato waste & Melamine & 6.2 & 255 & 0.5 & 93.7 & [92] \\
\hline Agricultural waste & Urea & 2.63 & 259.5 & 1.0 & 95 & [93] \\
\hline Waste lotus stems & Urea & & 360.5 & 0.5 & 96 & [94] \\
\hline Cellulose & Urea & 3.0 & 300 & 0.5 & 81 & [95] \\
\hline Lecithin & Urea & 9.2 & 285 & 0.5 & 81.3 & [96] \\
\hline Sugarcane bagasse & polypyrrole & 3.1 & 371 & 0.1 & 71.5 & [97] \\
\hline Cellulose aerogel & Urea & 4.62 & 225 & 0.5 & 81 & [98] \\
\hline
\end{tabular}

Different strategies have been explored to reach superior electrochemical and textural properties for carbon derivatives. One of the most straightforward procedures that have been applied in the modification of porous carbon structures (incorporation of nitrogen into carbon structure) refers to the post-treatment of porous structure with ammonia gas and urea [79]. Table 2 shows the more relevant results for $\mathrm{N}$-doped biomass-derived electrodes for SCs.

As can be seen, nitrogen-containing compounds such as urea, ammonia, thiourea, polyimide, polypyrrole, melamine, and cyanamide are essential candidates to be incorporated as nitrogen sources for direct pyrolisis of carbon-based sources (see Table 2).

As alternatives for this method of preparation, Zou et al. [79] reported a typical strategy that introduces advantages concerning the scale-up related advantages for the production of porous carbon based on the carbonization of biomass [92]. The authors explored the Juncus (biomass feedstock) as a carbon source to produce N-doped hierarchical porous structures, using $\mathrm{ZnCl}_{2}$ as an activation reagent. This process is successfully applied in plenty of carbon source-based materials such as Lycium barbarum L., water hyacinth, and bacterial cellulose [99].

Another possibility refers to the use of potato residues (carbon source) integrated with melamine (nitrogen source) and $\mathrm{ZnCl}_{2}$ as a pore-forming component [94].

Yang et al. [75] reported the production of N-doped porous carbon nanofiber aerogel, prepared from the pyrolysis at a high temperature of a carbon source and a nitrogen source (melamine).

In all of these methods, it is observed that an essential step for the production of highly efficient substrates for $\mathrm{N}$-doped supercapacitors refers to the previous activation for the production of higher surface area material with hierarchical opened pores [79].

On the other hand, the reaction with K-species enhances the carbon etching, improving the pore structure of the resulting material, characterizing an essential step for producing materials with desirable electrochemical and textural properties for electrodes with fast adsorption-desorption reactions that connect EDLC and pseudocapacitance reactions. 


\section{Challenges and Future Perspectives}

Regarding the AC preparation for energy storage applications, biomass residues as precursors play a crucial role in the development of greener and sustainable CE synthesis process due to its colossal availability and abundance found in every corner of the world.

There is still a gap in the understanding of selecting proper and suitable biomass resources to obtain desirable micro and nanostructures (in terms of pore shapes and sizes) through AC preparation methods, correlating these characteristics on the electrochemical performances. In particular, the intrinsic combination of the high surface area of EDLC candidates with the pseudocapacitive contribution of a second component can be achieved by procedure of nitrogen-doping of resulting structures, in which many aspects need to be evaluated and explored, such as which N-dopant and at which proportion during the AC preparation and applications should be explored and optimized. In contrast, the present studies lack to provide such information. The effective controlling of concentration and their ratio of different doping species are both difficult during the pyrolysis and activation process.

The lack of additional information concerning the electrochemical mechanisms induced by the heteroatom doping effect on biomass-based AC is an essential step toward the complete evaluation of the prominent advantages in terms of the rate capability, chemical stability, cycling performance, and capacitive retention.

The study about a single step experiment for the production of $\mathrm{N}$-doped carbon derivative processes reinforces the possibility of using a low-cost and straightforward procedure to produce all green devices with required properties of energy density and power density to be mutually competitive with conventional batteries and capacitors.

Further development to scale-up the fabrication of biomass AC electrodes to produce suitable and efficient CEs for electrochemical energy devices, including SCs, lithium-ion batteries, etc., is required.

The next step forward for the industry requires the green route to produce materials with outstanding performance and long-range hybrid vehicles' performance. The toxic compounds of conventional batteries must be urgently substituted by environmentally friendly compounds that explore biomass residues as carbon sources.

\section{Conclusions}

Biomass plays a major role due to the chemical diversity and inherent structures of ACs. The biomass related precursors may lead to the next-generation energy storage devices with similar and/or better electrochemical performances to push forward alternative electrodes' technology than fossil-derived materials. In this review, the different carbon materials prepared from various biomass precursors with chemical activation have been discussed, and the nitrogen doping effects on electrochemical performances.

The low cost and environmentally friendly aspects of heteroatom-doped structures from biomass are critical advantages for producing outstanding electrochemical components for electrodes of a supercapacitor. The self-doping provided by sources rich in nitrogen introduces adequate pseudocapacitive contribution added to the electrical double layer contribution of highly porous structures to reach high power density and competitive energy density in the state of art supercapacitors. The adequate balance among parameters from the preparation conditions represents the most critical condition for producing materials with outstanding electrochemical performance.

Author Contributions: Conceptualization, G.S.d.R.; investigation, G.S.d.R.; data curation, G.S.d.R.; writing—original draft, G.S.d.R.; funding acquisition, S.H.L.; writing—review and editing, S.H.L., H.P.d.O., M.T. and E.C.L. All authors have read and agreed to the published version of the manuscript.

Funding: This research was funded by Treesearch Postdoctoral program, Bio4Energy, a Strategic Research Environment appointed by the Swedish government, and the Swedish University of Agricultural Sciences.

Institutional Review Board Statement: Not applicable. 
Informed Consent Statement: Not applicable.

Conflicts of Interest: The authors declare no conflict of interest.

\section{References}

1. Pandey, G. Biomass-based bio-electro fuel cells based on carbon electrodes: An alternative source of renewable energy. SN Appl. Sci. 2019, 1, 408. [CrossRef]

2. Xie, J.; Zhang, Q. Recent Progress in Multivalent Metal (Mg, Zn, Ca, and Al) and Metal-Ion Rechargeable Batteries with Organic Materials as Promising Electrodes. Small 2019, 15, 1805061. [CrossRef]

3. Wang, K.; Bi, R.; Huang, M.; Lv, B.; Wang, H.; Li, C.; Wu, H.; Zhang, Q. Porous Cobalt Metal-Organic Frameworks as Active Elements in Battery-Supercapacitor Hybrid Devices. Inorg. Chem. 2020, 59, 6808-6814. [CrossRef] [PubMed]

4. Lee, J.; Srimuk, P.; Fleischmann, S.; Su, X.; Hatton, T.A.; Presser, V. Redox-electrolytes for non-flow electrochemical energy storage: A critical review and best practice. Progress Mat. Sci. 2019, 101, 46-89. [CrossRef]

5. Simon, P.; Gogotsi, Y.; Dunn, B. Where do batteries end and supercapacitors begin? Science 2014, 343, 1210-1211. [CrossRef]

6. Miller, J.R.; Burke, A.F. Electrochemical capacitors: Challenges and opportunities for real-world applications. Electrochem. Soc. Interface 2008, 17, 53. [CrossRef]

7. Zhao, Y.; Dong, C.; Sheng, L.; Xiao, Z.; Jiang, L.; Li, X.; Jiang, M.; Shi, J. Heteroatom-Doped Pillared Porous Carbon Architectures with Ultrafast Electron and Ion Transport Capabilities under High Mass Loadings for High-Rate Supercapacitors. ACS Sustain. Chem. Eng. 2020, 8, 8664-8674. [CrossRef]

8. dos Reis, G.S.; Larsson, S.H.; de Oliveira, H.P.; Thyrel, M.; Claudio Lima, E. Sustainable Biomass Activated Carbons as Electrodes for Battery and Supercapacitors-A Mini-Review. Nanomaterials 2020, 10, 1398. [CrossRef]

9. Li, Y.; Zheng, K.; Ali Shan, S.A.; Huang, Y.; Tian, Y.; Cheng, J.; Zhang, J. Winter-jujube-derived carbon with self-doped heteroatoms and a hierarchically porous structure for high-performance supercapacitors. RSC Adv. 2017, 7, 43356-43365.

10. Zhang, Y.L.; Sun, C.; Tang, Z.S. High specific capacitance and high energy density supercapacitor electrodes enabled by porous carbon with multilevel pores and self-doped heteroatoms derived from Chinese date. Diam. Relat. Mater. 2019, $97,107455$. [CrossRef]

11. Hu, X.; Li, J.; Zhang, Y.; Wu, Q.; Xia, G. Heteroatoms (N-, Si-) self-doped spongy carbon derived from wild fungus sharia bambusicola as electrode materials for supercapacitors. Chem. Phys. 2019, 525, 110383. [CrossRef]

12. Ma, Y.; Zhang, X.; Liang, Z.; Wang, C.; Sui, Y.; Zheng, B.; Ye, Y.; Ma, W.; Zhao, Q.; Qin, C. B/P/N/O co-doped hierarchical porous carbon nanofiber self-standing film with high volumetric and gravimetric capacitance performances for aqueous supercapacitors. Electrochim. Acta 2020, 337, 135800. [CrossRef]

13. Yan, D.; Guo, D.C.; Lu, A.H.; Dong, X.L.; Li, W.C. One-pot synthesis of unique skin-tissue-bone structured porous carbons for enhanced supercapacitor performance. J. Colloid Interface Sci. 2019, 557, 519-527. [CrossRef] [PubMed]

14. Thue, P.S.; Umpierres, C.S.; Lima, E.C.; Lima, D.R.; Machado, F.M.; Reis, G.S.d.; Silva, R.S.; Pavan, F.A.; Tran, H.N. Single-step pyrolysis for producing magnetic activated carbon from tucumã (Astrocaryum aculeatum) seed and nickel(II) chloride and zinc(II) chloride. Application for removal of nicotinamide and propranolol. J. Hazard. Mat. 2020, 398, 122903. [CrossRef]

15. Reis, G.S.d.; Adebayo, M.A.; Lima, E.C.; Sampaio, C.H.; Prola, L.D.T. Activated carbon from sewage sludge for preconcentration of copper. Anal. Lett. 2016, 49, 541-555. [CrossRef]

16. Reis, G.S.D.; Wilhelm, M.; Silva, T.C.A.; Rezwan, K.; Sampaio, C.H.; Lima, E.C.; Souza, S.M.A.G.U. The use of the design of experiments for the evaluation of the production of surface rich activated carbon from sewage sludge via microwave and conventional pyrolysis. Appl. Therm. Eng. 2016, 93, 590-597. [CrossRef]

17. Kasperiski, F.M.; Lima, E.C.; Umpierres, C.S.; Reis, G.S.d.; Thue, P.S.; Lima, D.R.; Dias, S.L.P.; Saucier, C.; da Costa, J.B. Production of porous activated carbons from Caesalpinia ferrea seed pod wastes: Highly efficient removal of captopril from aqueous solutions. J. Clean. Prod. 2018, 197, 919-929. [CrossRef]

18. Cunha, M.R.; Lima, E.C.; Cimirro, N.F.G.M.; Thue, P.S.; Dias, S.L.P.; Gelesky, M.A.; Dotto, G.L.; Reis, G.S.d.; Pavan, F.A. Conversion of Eragrostis plana Nees leaves to activated carbon by microwave-assisted pyrolysis for the removal of organic emerging contaminants from aqueous solutions. Environ. Sci. Pollut. Res. 2018, 25, 23315-23327. [CrossRef] [PubMed]

19. Lua, A.C.; Yang, T. Effects of vacuum pyrolysis conditions on the characteristics of activated carbons derived from pistachio-nut shells. J. Colloid Interface Sci. 2005, 290, 505-513. [CrossRef]

20. Nuithitikul, K.; Srikhun, S.; Hirunpraditkoon, S. Influences of pyrolysis condition and acid treatment on properties of durian peel-based activated carbon. Bioresour. Technol. 2010, 101, 426-429. [CrossRef] [PubMed]

21. Huang, Y.-F.; Chiueh, P.-T.; Kuan, W.-H.; Lo, S.-L. Microwave pyrolysis of lignocellulosic biomass: Heating performance and reaction kinetics. Energy 2016, 100, 137-144.

22. Bouchelta, C.; Medjram, M.S.; Zoubida, M.; Chekkat, F.A.; Ramdane, N.; Bellat, J.-P. Effects of pyrolysis conditions on the porous structure development of date pits activated carbon. J. Anal. Appl. Pyrolysis 2012, 94, 215-222. [CrossRef]

23. Ahmad, M.; Lee, S.S.; Dou, X.; Mohan, D.; Sung, J.-K.; Yang, J.E.; Ok, Y.S. Effects of pyrolysis temperature on soybean stoverand peanut shell-derived biochar properties and TCE adsorption in watery. Bioresour. Technol. 2012, 118, 536-544. [CrossRef] [PubMed] 
24. Elnour, A.Y.; Alghyamah, A.A.; Shaikh, H.M.; Poulose, A.M.; Al-Zahrani, S.M.; Anis, A.; Al-Wabel, M.-I. Effect of Pyrolysis Temperature on Biochar Microstructural Evolution, Physicochemical Characteristics, and Its Influence on Biochar/Polypropylene Composites. Appl. Sci. 2019, 9, 1149. [CrossRef]

25. Soltani, S.M.; Yazdi, S.K.; Hosseini, S. Effects of pyrolysis conditions on the porous structure construction of mesoporous charred carbon from used cigarette filters. Appl. Nanosci. 2014, 4, 551-569. [CrossRef]

26. Okonkwo, C.A.; Lv, T.; Hong, W.; Li, G.; Huang, J.; Deng, J.; Jia, L.; Wu, M.; Liu, H.; Guo, M. The synthesis of micro mesoporous carbon derived from nitrogen-rich spirulina extract impregnated castor shell based on biomass self-doping for highly efficient supercapacitor electrodes. J. Alloys Compd. 2020, 825, 154009. [CrossRef]

27. Song, X.; Ma, X.; Li, Y.; Ding, L.; Jiang, R. Tea waste-derived microporous active carbon with enhanced double-layer supercapacitor behaviors. Appl. Surface Sci. 2019, 487, 189-197. [CrossRef]

28. Sun, L.; Tian, C.; Li, M.; Meng, X.; Wang, L.; Wang, R.; Yin, J.; Fu, H. From coconut shell to porous graphene-like nanosheets for high-power supercapacitors. J. Mater. Chem. A 2013, 1, 6462-6470. [CrossRef]

29. Zhao, B.; O'Connor, D.; Zhang, J.; Peng, T.; Shen, Z.; Tsang, D.C.W.; Hou, D. Effect of pyrolysis temperature, heating rate, and residence time on rapeseed stem derived biochar. J. Clean. Prod. 2018, 174, 977-987. [CrossRef]

30. Hou, J.; Jiang, K.; Tahir, M.; Wu, X.; Idrees, F.; Shen, M.; Cao, C. Tunable porous structure of carbon nanosheets derived from puffed rice for high energy density supercapacitors. J. Power Sources 2017, 371, 148-155. [CrossRef]

31. Gao, Y.; Yue, Q.; Gao, B.; Li, A. Insight into activated carbon from different kinds of chemical activating agents: A review. Sci. Total Environ. 2020, 746, 141094. [CrossRef] [PubMed]

32. Bedia, J.; Peñas-Garzón, M.; Gómez-Avilés, A.; Rodriguez, J.J.; Belver, C. Review on Activated Carbons by Chemical Activation with $\mathrm{FeCl}_{3}$. J. Carbon Res. 2020, 6, 21. [CrossRef]

33. Danish, M.; Ahmad, T. A review on the utilization of wood biomass as a sustainable precursor for activated carbon production and application. Renew. Sustain. Energ. Rev. 2018, 87, 1-21. [CrossRef]

34. Peng, L.; Cai, Y.; Luo, Y.; Yuan, G.; Huang, J.; Hu, C.; Dong, H.; Xiao, Y.; Liang, Y.; Liu, Y.; et al. Bio-inspired highly crumpled porous carbons with multidirectional porosity for high rate performance electrochemical supercapacitors. ACS Sustain. Chem. Eng. 2018, 6, 12716-12726. [CrossRef]

35. Cunha, M.R.; Lima, E.C.; Lima, D.R.; da Silva, R.S.; Thue, P.S.; Seliem, M.K.; Sher, F.; dos Reis, G.S.; Larsson, S.H. Removal of captopril pharmaceutical from synthetic pharmaceutical-industry wastewaters: Use of activated carbon derived from Butia catarinensis. J. Environ. Chem. Eng. 2020, 8, 104506. [CrossRef]

36. Niu, J.; Shao, R.; Liang, J.; Dou, M.; Li, Z.; Huang, Y.; Wang, F. Biomass-derived mesopore-dominant porous carbons with large specific surface area and high defect density as high-performance electrode materials for Li-ion batteries and supercapacitors. Nano Energy 2017, 36, 322-330. [CrossRef]

37. Li, Y.; Zhang, D.; Zhang, Y.; He, J.; Wang, Y.; Wang, K.; Xu, Y.; Li, H.; Wang, Y. Biomass-derived microporous carbon with large micropore size for high-performance supercapacitors. J. Power Sources 2020, 448, 227396. [CrossRef]

38. Gou, G.; Huang, F.; Jiang, M.; Li, J.; Zhou, Z. Hierarchical porous carbon electrode materials for supercapacitor developed from wheat straw cellulosic foam. Renew. Energy 2020, 149, 208-216. [CrossRef]

39. Xu, D.; Hu, W.; Sun, X.N.; Cui, P.; Chen, X.Y. Redox additives of Na2MoO4 and KI: Synergistic effect and the improved capacitive performances for carbon-based supercapacitors. J. Power Sources 2017, 341, 448-456. [CrossRef]

40. Jiang, C.; Yakaboylu, G.A.; Yumak, T.; Zondlo, J.W.; Sabolsky, E.M.; Wang, J. Activated carbons prepared by indirect and direct CO2 activation of lignocellulosic biomass for supercapacitor electrodes. Renew. Energy 2020, 155, 38-52. [CrossRef]

41. Yakaboylu, G.A.; Jiang, C.; Yumak, T.; Zondlo, J.W.; Wang, J.; Sabolsky, E.M. Engineered hierarchical porous carbons for supercapacitor applications through chemical pretreatment and activation of biomass precursors. Renew. Energy 2021, 163, 276-287. [CrossRef]

42. Kang, D.; Liu, Q.; Gu, J.; Su, Y.; Zhang, W.; Zhang, D. “Egg-Box”-Assisted Fabrication of Porous Carbon with Small Mesopores for High-Rate Electric Double Layer Capacitors. ACS Nano 2015, 9, 11225-11233. [CrossRef]

43. Liu, J.; Min, S.; Wang, F.; Zhang, Z. Biomass-derived three-dimensional porous carbon membrane electrode for high-performance aqueous supercapacitors: An alternative of powdery carbon materials. J. Power Sources 2020, 466, 228347. [CrossRef]

44. Chen, H.; Liu, D.; Shen, Z.; Bao, B.; Zhao, S.; Wu, L. Functional biomass carbons with a hierarchical porous structure for supercapacitor electrode materials. Electrochim. Acta 2015, 180, 241-251. [CrossRef]

45. Tian, W.; Gao, Q.; Tan, Y.; Li, Z. Unusual, interconnected graphitized carbon nanosheets as the electrode of a high-rate ionic liquid-based supercapacitor. Carbon 2017, 119, 287-295. [CrossRef]

46. Guo, F.; Jiang, X.; Jia, X.; Liang, S.; Qian, L.; Rao, Z. Synthesis of biomass carbon electrode materials by bimetallic activation for the application in supercapacitors. J. Electroanal. Chem. 2019, 844, 105-115. [CrossRef]

47. Sevilla, M.; Diez, N.; Ferrero, G.A.; Fuertes, A.B. Sustainable supercapacitor electrodes produced by the activation of biomass with sodium thiosulfate. Energy Storage Mater. 2019, 18, 356-365. [CrossRef]

48. Liang, X.; Liu, R.; Wu, X. Biomass waste-derived functionalized hierarchical porous carbon with high gravimetric and volumetric capacitances for supercapacitors. Microporous Mesoporous Mater. 2021, 310, 110659. [CrossRef]

49. Zhou, X.; Li, H.; Yang, J. Biomass-derived activated carbon materials with plentiful heteroatoms for high-performance electrochemical capacitor electrodes. J. Energy Chem. 2016, 25, 35-40. [CrossRef] 
50. Ren, M.; Jia, Z.; Tian, Z.; Lopez, D.; Cai, J.; Titirici, M.M.; Jorge, A.B. High-performance n-doped carbon electrodes obtained via hydrothermal carbonization of macroalgae for supercapacitor applications. ChemElectroChem 2018, 5, 2686-2693. [CrossRef]

51. Cao, Q.; Zhang, Y.; Chen, J.; Zhu, M.; Yang, C.; Guo, H.; Song, Y.; Li, Y.; Zhou, J. Electrospun biomass-based carbon nanofibers as high-performance supercapacitors. Ind. Crops Prod. 2020, 148, 112181. [CrossRef]

52. Divya, P.; Rajalakshmi, R. Renewable, low cost green functional mesoporous electrodes from Solanum lycopersicum leaves for supercapacitors. J Energy Storage 2020, 27, 101149. [CrossRef]

53. Wang, L.; Li, Z.; Yan, S.; Yu, X.; Ma, Y.; Ma, L. Modifying the microstructure of algae-based active carbon and modelling supercapacitors using artificial neural networks. RSC Adv. 2019, 9, 14797. [CrossRef]

54. Cai, Y.; Luo, Y.; Dong, H.; Zhao, X.; Xiao, Y.; Liang, Y.; Hu, H.; Liu, Y.; Zheng, M. Hierarchically porous carbon nanosheets derived from Moringa oleifera stem as electrode material for high-performance electric double-layer capacitors. J. Power Sources 2017, 353, 260-269. [CrossRef]

55. Zheng, L.H.; Chen, M.H.; Liang, S.X.; Lü, Q.F. Oxygen-rich hierarchical porous carbon derived from biomass waste-kapok flower for supercapacitor electrode. Diam. Relat. Mat. 2021, 113, 108267. [CrossRef]

56. Jain, A.; Ghosh, M.; Krajewski, M.; Kurungot, S.; Michalsk, M. Biomass-derived activated carbon material from native European deciduous trees as an inexpensive and sustainable energy material for supercapacitor application. J. Energy Storage 2021, 34, 102178. [CrossRef]

57. Vinayagam, M.; Babu, R.S.; Sivasamy, A.; Barros, A.L.F. Biomass-derived porous activated carbon from Syzygium cumini fruit shells and Chrysopogon zizanioides roots for high-energy-density symmetric supercapacitors. Biomass Bioenergy 2020, 143, 105838. [CrossRef]

58. Sun, Y.; Xue, J.; Dong, S.; Zhang, Y.; An, Y.; Ding, B.; Zhang, T.; Dou, H.; Zhang, X. Biomass-derived porous carbon electrodes for high-performance supercapacitors. J. Mater. Sci. 2020, 55, 5166-5176. [CrossRef]

59. Jung, S.M.; Mafra, D.L.; Lin, C.-T.; Jung, H.Y.; Kong, J. Controlled porous structures of graphene aerogels and their effect on supercapacitor performance. Nanoscale 2015, 7, 3486-4393. [CrossRef]

60. Zhang, D.; Han, M.; Wang, B.; Li, Y.; Lei, L.; Wang, K.; Wang, Y.; Zhang, L.; Feng, H. Superior supercapacitors based on nitrogen and sulfur co-doped hierarchical porous carbon: Excellent rate capability and cycle stability. J. Power Sources 2017, 358, 112-120. [CrossRef]

61. Chmiola, T.; Yushin, G.; Gogotsi, Y.; Portet, C.; Simon, P.; Taberna, P.L. Anomalous increase in carbon capacitance at pore sizes less than 1 nanometer. Science 2006, 313, 1760-1763. [CrossRef]

62. Zhou, M.; Pu, F.; Wang, Z.; Guan, S. Nitrogen-doped porous carbons through $\mathrm{KOH}$ activation with superior performance in supercapacitors. Carbon 2014, 68, 185-194. [CrossRef]

63. Kim, H.-K.; Lee, M.S.; Lee, S.-Y.; Choi, Y.-W.; Jeong, N.-J.; Kim, C.S. High power density of reverse electrodialysis with pore-filling ion exchange membranes and a highopen-area spacer. J. Mater. Chem. A 2015, 3, 16302.

64. Miao, L.; Duan, H.; Wang, Z.; Lv, Y.; Xiong, W.; Zhu, D.; Gan, L.; Li, L.; Liu, M. Improving the pore-ion size compatibility between poly(ionic liquid)- derived carbons and high-voltage electrolytes for high energy-power supercapacitors. Chem. Eng. J. 2020, 382, 122945. [CrossRef]

65. Li, X.; Zhang, H.; Mai, Z.; Zhang, H.; Vankelecom, I. Ion exchange membranes for vanadium redox flow battery (VRB) applications. Energy Environ. Sci. 2011, 4, 1147-1160. [CrossRef]

66. Olivares-Marín, M.; Aklalouch, M.; Tonti, D. Combined Influence of Meso- and Macroporosity of Soft-Hard Templated Carbon Electrodes on the Performance of Li-O2 Cells with Different Configurations. Nanomaterials 2019, 9, 810. [CrossRef] [PubMed]

67. Bokhari, S.W.; Siddique, A.H.; Pan, H.; Li, Y.; Imtiaz, M.; Chen, Z.; Zhu, S.M.; Zhang, D. Nitrogen doping in the carbon matrix for Li-ion hybrid supercapacitors: State of the art, challenges and future prospective. RSC Adv. 2017, 7, 18926-18936. [CrossRef]

68. Xu, X.; Zhang, S.; Tang, J.; Pan, L.; Eguchi, M.; Na, J.; Yamauchi, Y. Nitrogen-doped nanostructured carbons: A new material horizon for water desalination by capacitive deionization. EnergyChem 2020, 2, 100043. [CrossRef]

69. Gopalakrishnan, A.; Badhulika, S. Effect of self-doped heteroatoms on the performance of biomass-derived carbon for supercapacitor applications. J. Power Sources 2020, 480, 228830. [CrossRef]

70. Wan, Z.; Sun, Y.; Tsang, D.C.W.; Khan, E.; Yip, A.C.K.; Ng, Y.H.; Rinklebe, J.; Ok, Y.S. Customised fabrication of nitrogen-doped biochar for environmental and energy applications. Chem. Eng. J. 2020, 401, 126136. [CrossRef]

71. Zhu, C.; Li, H.; Fu, S.; Du, D.; Lin, Y. Highly efficient nonprecious metal catalysts towards oxygen reduction reaction based on three-dimensional porous carbon nanostructures. Chem. Soc. Rev. 2016, 45, 517-531. [CrossRef]

72. Geng, D.; Yang, S.; Zhang, Y.; Yang, J.; Liu, J.; Li, R.; Sham, T.-K.; Sun, X.; Ye, S.; Knights, S. Nitrogen doping effects on the structure of graphene. Appl. Surf. Sci. 2011, 257, 9193-9198. [CrossRef]

73. Xu, X.; Pan, L.; Liu, Y.; Lu, T.; Sun, Z. Enhanced capacitive deionization performance of graphene by nitrogen doping. J. Colloid Interface Sci. 2015, 445, 143-150. [CrossRef]

74. Deng, J.; Li, J.; Song, S.; Zhou, Y.; Li, L. Electrolyte-dependent supercapacitor performance on nitrogen-doped porous bio-carbon from gelatin. Nanomaterials 2020, 10, 353. [CrossRef] [PubMed]

75. Yang, Y.; Liu, Y.-X.; Li, Y.; Deng, B.W.; Yin, B.; Yang, M.B. Design of compressible and elastic N-doped porous carbon nanofiber aerogels as binder-free supercapacitor electrodes. J. Mater. Chem. A 2020, 8, 17257-17265. [CrossRef]

76. He, G.; Yang, G.; Song, Y.; Wang, L. Biomass Juncus Derived Nitrogen-Doped Porous Carbon Materials for Supercapacitor and Oxygen Reduction Reaction. Front. Chem. 2020, 8, 226. [CrossRef] [PubMed] 
77. Chen, L.F.; Zhang, X.D.; Liang, H.W.; Kong, M.; Guan, Q.F.; Chen, P.; Wu, Z.Y.; YU, S.H. Synthesis of nitrogen-doped porous carbon nanofibers as an efficient electrode material for supercapacitors. ACS Nano 2012, 6, 7092-7102. [CrossRef] [PubMed]

78. Yang, W.; Yang, W.; Kong, L.; Song, A.; Qin, X. Facile synthesis of nitrogen-doped porous carbon for high-performance supercapacitors. RSC Adv. 2017, 7, 55257-55263. [CrossRef]

79. Zou, B.X.; Wang, Y.; Huang, X.; Lu, Y. Hierarchical N- and O-Doped porous carbon composites for high-performance supercapacitors. J. Nanomater. 2018, 2018, 8945042. [CrossRef]

80. Zhang, J.; Chen, H.; Bai, J.; Xu, M.; Luo, C.; Yang, L.; Bai, L.; Wei, D.; Wang, W.; Yang, H. N-doped hierarchically porous carbon derived from grape marcs for high-performance supercapacitors. J. Alloys Compd. 2021, 854, 157207. [CrossRef]

81. Sun, S.; Han, F.; Wu, X.; Fan, Z. One-step synthesis of biomass-derived O, N-codoped hierarchical porous carbon with the high surface area for supercapacitors. Chin. Chem. Lett. 2020, 31, 2235-2238. [CrossRef]

82. Ahmed, S.; Rafat, M.; Ahmed, A. Nitrogen doped activated carbon derived from orange peel for supercapacitor application. Adv. Nat. Sci: Nanosci. Nanotechnol. 2018, 9, 035008. [CrossRef]

83. Lin, G.; Ma, R.; Zhou, Y.; Liu, Q.; Dong, X.; Wang, J. KOH activation of biomass-derived nitrogen-doped carbons for supercapacitor and electrocatalytic oxygen reduction. Electrochim. Acta 2018, 261, 49-57. [CrossRef]

84. Lin, Y.; Chen, Z.; Ying, C.; Zhong, W. Facile synthesis of high nitrogen-doped content, mesopore-dominate biomass-derived hierarchical porous graphitic carbon for high-performance supercapacitors. Electrochim. Acta 2020, 334, 135615. [CrossRef]

85. Liang, J.-Y.; Wang, C.-C.; Lu, S.-Y. Glucose-derived nitrogen-doped hierarchical hollow nest-like carbon nanostructures from a novel template-free method as an outstanding electrode material for supercapacitors. J. Mater. Chem. A 2015, 3, 24453-24462. [CrossRef]

86. Wei, H.; Chen, J.; Fu, N.; Cheny, H.; Lin, H.; Han, S. Biomass-derived nitrogen-doped porous carbon with superior capacitive performance and high $\mathrm{CO}_{2}$ capture capacity. Electrochimi. Acta 2018, 266, 161-169162. [CrossRef]

87. Wang, S.; Dong, L.; Li, Z.; Lin, N.; Xu, H.; Gao, S. Sustainable supercapacitors of nitrogen-doping porous carbon-based on cellulose nanocrystals and urea. Int. J. Biol. Macromol. 2020, 164, 4095-4103. [CrossRef]

88. Yang, S.; Yang, W.; Song, A.; Gao, L.; Su, L.; Shao, G. Supercapacitance of nitrogen-sulfur-oxygen co-doped 3D hierarchical porous carbon in aqueous and organic electrolyte. J. Power Sources 2017, 359, 556-567557. [CrossRef]

89. Gao, F.; Shao, G.; Qu, J.; Lv, L.; Li, Y.; Wu, M. Tailoring of porous and nitrogen-rich carbons derived from hydrochar for high-performance supercapacitor electrodes. Electrochim. Acta 2015, 155, 201-208. [CrossRef]

90. Wen, Y.; Chi, L.; Wenelska, K.; Wen, X.; Chen, X.; Mijowska, E. Eucalyptus derived heteroatom-doped hierarchical porous carbons as electrode materials in supercapacitors. Sci. Rep. 2020, 10, 14631. [CrossRef]

91. Jiang, M.; Yu, X.; Gao, R.; Yang, T.; Xu, Z.; Cao, L. Fabrication of Biomass-Derived N, S Co-doped Carbon with Hierarchically Porous Architecture for High-Performance Supercapacitor. NANO Brief Rep. Rev. 2020, 15, 2050096. [CrossRef]

92. Ma, G.; Yang, Q.; Sun, K.; Peng, H.; Ran, F.; Zhao, X.; Lei, Z. Nitrogen-doped porous carbon derived from biomass waste for high-performance supercapacitor. Bioresource Technol. 2015, 197, 137-142. [CrossRef] [PubMed]

93. Zou, K.; Deng, Y.; Chen, J.; Qian, Y.; Yang, Y.; Li, Y.; Chen, G. Hierarchically porous nitrogen-doped carbon derived from the activation of agriculture waste by potassium hydroxide and urea for high-performance supercapacitors. J. Power Sources 2018, 378, 579-588. [CrossRef]

94. Yan, G.; Lin, J.; Liu, P.; Zhao, Z.; Lian, J.; Chang, W.; Yao, L.; Liu, Y.; Lin, H.; Han, S. Preparation of nitrogen-doped porous carbons for high-performance supercapacitor using biomass of waste lotus stems. RSC Adv. 2018, 8, 6806-6813. [CrossRef]

95. Song, P.; Shen, X.P.; He, X.M.; Feng, K.H.; Kong, L.R.; Ji, Z.Y.; Zhai, L.Z.; Zhu, G.X.; Zhang, D.Y. Cellulose-derived nitrogen-doped hierarchically porous carbon for high-performance supercapacitors. Cellulose 2019, 26, 1195-1208. [CrossRef]

96. Demir, M.; Saraswat, S.K.; Gupta, R.B. Hierarchical nitrogen-doped porous carbon derived from lecithin for high-performance supercapacitors. RSC Adv. 2017, 7, 42430. [CrossRef]

97. Wang, B.; Wang, Y.; Peng, Y.; Wang, Y.; Wang, N.; Wang, J.; Zhao, J. Nitrogen-doped biomass-based hierarchical porous carbon with large mesoporous volume for application in energy storage. Chem. Eng. J. 2018, 348, 850-859. [CrossRef]

98. Hu, Y.; Tong, X.; Zhuo, H.; Zhong, L.; Peng, X.; Wang, S.; Sun, R. 3D hierarchical porous N-doped carbon aerogel from renewable cellulose: An attractive carbon for high-performance supercapacitor electrodes and CO2 adsorption. RSC Adv. 2016, 6, 15788-15795. [CrossRef]

99. Lia, J.; Luo, F.; Lin, T.; Yang, J.; Yang, S.; He, D.; Xiao, D.; Liu, W. Pomelo peel-based N, O-codoped hierarchical porous carbon material for supercapacitor application. Chem. Phys. Lett. 2020, 753, 137597. [CrossRef] 